\title{
MANAJEMEN LABA (EARNING MANAGEMENT) DALAM \\ PERSPEKTIF ETIKA HEDONISME
}

\author{
Radian Sri Rama
}

Universitas Brawijaya

Jl. Veteran Malang 65145 Indonesia

\begin{abstract}
Earnings management occurs as a direct consequence of the efforts of managers or preparers of financial statements for management accounting information, especially earnings for the sake of personal interests or companies. That earnings management can not be interpreted as a negative action since it does not profit-oriented management of earnings manipulation. Positive accounting theory suggests that managers have an incentive or encouragement to be able to maximize their welfare. In this paper the behavior of managers in the conduct of earnings management will be reviewed from the standpoint of ethical hedonism. Used in the sense of ethical values and moral norms which become the handle for one person or a group to regulate behavior hedonism Ethics plays an important role of earnings management. Because hedonism starting from the assumption that human beings should live in such a way that it can be more happy. Efforts to gain reward management priorities, reward obtained by showing a stable performance from several periods. Earning management one way to show achievement. By looking at two perspectives of psychological hedonism and ethical hedonism, it can be drawn a conclusion that earning management is a reasonable action to meet the man himself hedonism.
\end{abstract}

Keywords: Earnings Management, Positive Accounting Theory, Ethical Hedonism

Manajemen laba, akhir-akhir ini merupakan sebuah fenomena umum yang terjadi di sejumlah perusahaan. Praktik yang dilakukan untuk mempengaruhi angka laba dapat terjadi secara legal maupun tidak legal. Praktik legal dalam manajemen laba berarti usaha untuk mempengaruhi angka laba tidak bertentangan dengan aturan pelaporan keuangan dalam Prinsip-Prinsip Akuntansi Berterima Umum (PABU), khususnya dalam Standar Akuntansi, yaitu dengan cara memanfaatkan peluang untuk membuat estimasi akuntansi, melakukan perubahan 
metode akuntansi, dan menggeser periode pendapatan atau biaya. Adapun manajemen laba yang dilakukan secara illegal (disebut juga dengan financial fraud), dilakukan dengan cara-cara yang tidak diperbolehkan oleh Pedoman Akuntansi Berterima Umum (PABU), yaitu dengan cara melaporkan transaksitransaksi pendapatan atau biaya secara fiktif dengan cara menambah (mark up) atau mengurangi (mark down) nilai transaksi, atau mungkin dengan tidak melaporkan sejumlah transaksi, sehingga akan menghasilkan laba pada nilai/tingkat tertentu yang dikehendaki.

Kasus manajemen laba yang dilakukan dengan cara illegal (financial fraud) telah banyak terjadi di sejumlah perusahaan, seperti Enron Corporation, Xerox Corporation, WordCom, Walt Disney Company, dan lainnya. Enron Corporation terbukti melakukan manipulasi laba, yaitu melakukan manipulasi eksekutif Enron melalui lembaga auditornya sehingga dapat mendongkrak laba mendekati USD 1 miliar. Padahal, eksekutif Enron hanya menikmati angka semu yang sebetulnya laba tersebut tidak pernah mereka dapatkan. Xerox Corporation terbukti melakukan manipulasi pendapatan akuntansi, yaitu melakukan manipulasi pembukuan atas pendapatan (revenue) perusahaan sebesar USD 6 miliar. Jumlah tersebut tidak sama dengan taksiran Securities and Exchange Commision (SEC) yang saat itu nilainya dari 1997 sampai 2000 menurut pengawas pasar modal AS diperkirakan hanya sebesar USD 3 milliar. WordCom terbukti melakukan manipulasi pengeluaran akuntansi, yaitu melakukan manipulasi pembukuan senilai USD 4 miliar pada sisi pengeluaran. Skandal ini diduga melibatkan Arthur Andersen dan Walt Disney Company terbukti telah melakukan manipulasi pendapatan akuntansi, yaitu melakukan manipulasi data akuntansi untuk dua 
tahun fiskal. Menurut Disney, pendapatan pada tahun 2001 adalah USD 613 juta, atau 29 sen per lembar saham, padahal sesungguhnya hanya sebesar USD 358 juta atau 17 sen per lembar saham (Kompas, 2002).

Berbagai kasus financial fraud umumnya dilakukan dengan cara bekerja sama dengan pihak-pihak lain seperti Kantor Akuntan Publik (auditor), pejabat tinggi negara, supplier, dan pihak lainnya yang mempunyai hubungan keuangan dengan perusahaan. Misalnya kasus WordCom di atas yang bekerjasama dengan perusahaan akuntan publik Arthur Anderson telah merekayasa laporan keuangan untuk menutup kerugiannya dengan cara memanipulasi keuntungan perusahaan menjadi lebih besar. Sejumlah kasus financial fraud lainnya juga banyak yang mencuat ke publik pada tahun 2000-an dan menyebabkan sejumlah perusahaan bangkrut. Kasus tersebut terungkap ke publik bahwa pihak manajemen berkonspirasi dengan pihak-pihak tertentu dalam melakukan penipuan akuntansi, sehingga merugikan banyak pihak.

Persoalan manajemen laba sebetulnya bukan hal yang baru dalam praktik pelaporan keuangan (financial reporting) pada suatu entitas bisnis. Hal ini disebabkan oleh kejamnya pasar kepada perusahaan yang tidak mampu memenuhi target atau meleset dari yang diperkirakan oleh pasar. Tekanan untuk membuat keuntungan ini kerap terasa dampaknya pada perolehan pendapatan (income) bagi manajemen, sehingga manajemen melakukan manajemen laba untuk mempengaruhi angka laba yang menyebabkan terjadinya penurunan kualitas laporan keuangan perusahaan bersangkutan

Penurunan kualitas laporan keuangan merupakan dampak utama yang diakibatkan dari adanya manajemen laba, di samping dampak-dampak lainnya. 
Setiawati dan Na'im (2000) menyatakan bahwa manajemen laba merupakan salah satu faktor yang dapat mengurangi kredibilitas laporan keuangan. Manajemen laba menambah bias dalam laporan keuangan dan dapat mengganggu pemakai laporan keuangan yang mempercayai angka laba hasil rekayasa tersebut sebagai angka laba tanpa rekayasa. Dalam pandangan orang awam, manajemen laba dianggap tidak etis, bahkan merupakan bentuk dari manipulasi informasi sehingga menyesatkan.

Penelitian ini akan membahas manajemen laba (earnings management) ditinjau dari sudut pandang etika dengan maksud untuk melihat bagaimana pandangan etika mengenai manajemen laba. Etika merupakan bidang ilmu normatif yang dapat menentukan apa yang harus dilakukan atau tidak dilakukan oleh seorang individu (Beekun, 1997:196). Etika bisnis merujuk kepada etika manajemen atau etika organisasi yang membatasi kerangka acuannya kepada konsepsi sebuah organisasi. Bertens (2000:33) merumuskan pengertian etika kepada tiga pengertian, yaitu: pertama, etika digunakan dalam pengertian nilainilai dan norma-norma moral yang menjadi pegangan bagi seseorang atau suatu kelompok dalam mengatur tingkah lakunya. Kedua, etika merupakan kumpulan asas atau nilai moral atau kode etik. dan Ketiga, etika merupakan ilmu yang mempelajari tentang sesuatu hal yang baik dan buruk.

Perspektif etika terhadap suatu tindakan atau aktivitas bisnis sangat penting, karena etika bisnis dapat digunakan sebagai cara untuk menyelaraskan kepentingan strategis suatu bisnis atau perusahaan dengan tuntutan moralitas (Beekun, 1997:201). Penyelarasan tersebut berarti merupakan sebuah upaya untuk merekonstruksi pemahaman tentang bisnis dan sekaligus mengimplementasikan 
bisnis sebagai media usaha atau perusahaan yang bersifat etis. Etika bisnis juga dapat melakukan perubahan kesadaran masyarakat tentang bisnis dengan memberikan suatu pemahaman atau cara pandang baru, yakni bahwa bisnis tidak terpisah dari (Beekun, 1997:202).

Etika bisnis, berarti sebuah pemikiran atau refleksi tentang moralitas yang membatasi kerangka acuannya kepada konsepsi sebuah organisasi dalam ekonomi dan bisnis yang didasarkan moral. Etika bisnis mengatur tentang sesuatu yang baik atau buruk, wajar atau tidak wajar, atau diperbolehkan atau tidaknya perilaku manusia dalam aktivitas bisnis baik dalam lingkup individu maupun organisasi yang didasarkan atas moral dan etika. Dalam hal ini, penelitian ini akan berusaha melihat aspek moralitas/normatif dari manajemen laba (earnings management), yaitu apakah manajemen laba merupakan sebuah tindakan yang baik atau buruk, wajar atau tidak wajar, diperbolehkan atau dilarang menurut perspektif etika hedonisme.

\section{PEMBAHASAN}

Selain bertanggung jawab untuk menampilkan performa terbaik perusahaan, manajemen juga bertanggung jawab untuk menyediakan laporan keuangan bagi semua pihak yang berkepentingan dengan informasi akuntansi perusahaan. Laporan keuangan merupakan sarana utama melalui mana informasi keuangan dikomunikasikan kepada pihak-pihak di luar perusahaan. Untuk itu, laporan keuangan harus mampu menggambarkan posisi keuangan dan hasil-hasil usaha perusahaan pada saat tertentu secara wajar (Dwiatmini dan Nurkholis, 2001). Laporan keuangan yang diterbitkan oleh perusahaan adalah salah satu 
sumber informasi mengenai posisi keuangan perusahaan, kinerja serta perubahan posisi keuangan perusahaan yang sangat berguna untuk pengambilan keputusan yang tepat (Almilia dan Kristiaji, 2003).

Salah satu informasi yang sangat penting untuk pengambilan keputusan adalah informasi atas laba. Informasi laba secara umum menjadi perhatian utama dalam penaksiran kinerja atau pertanggungjawaban manajemen. Informasi laba ini juga membantu pemilik atau pihak lain untuk melakukan penaksiran atas kekuatan laba perusahaan di masa yang akan datang (Harahap, 2004). Pentingnya informasi laba ini disadari oleh manajemen, sehingga manajemen cenderung melakukan disfunctional behaviour ( perilaku tidak semestinya ), yaitu dengan melakukan earning management atau manajemen laba untuk mengatasi berbagai konflik yang timbul antara manajemen dengan berbagai pihak yang berkepentingan dengan perusahaan (Sugiarto, 2003). Disfunctional behaviour tersebut dipengaruhi oleh adanya asimetri informasi (information asymetry) dalam konsep teori keagenan (agency theory).

Menurut Assih dan Gudono (2000), Earning Management atau Manajemen laba diartikan sebagai suatu proses yang dilakukan dengan sengaja, dalam batasan general accepted accounting principles, untuk mengarah pada suatu tingkat yang diinginkan atas laba yang dilaporkan. Perataan laba menurut Assih dan Gudono (2000), termasuk dalam pengertian manajemen laba tersebut, yaitu "cara pengurangan dalam variabilitas laba selama sejumlah periode tertentu atau dalam satu periode, yang mengarah pada tingkat yang diharapkan atas laba yang dilaporkan." 
Sedangkan definisi lainnya mengartikan manajemen laba sebagai suatu proses yang dilakukan dengan sengaja, dalam batasan general accepted accounting principles (Prasetio, 2002). Hal ini memang cukup banyak mengundang kontroversi, di satu sisi earnings management merupakan tindakan yang tidak menyalahi peraturan yang ada dan berlaku umum.

Dengan demikian perataan laba dapat dikatakan sebagai suatu cara yang dipakai manajemen untuk mengurangi variabilitas laba di antara deretan jumlah laba, yang timbul karena adanya perbedaan antara jumlah laba yang seharusnya dilaporkan dengan laba yang diharapkan (Expected Profit). Expected Profit adalah rata-rata tertimbang untuk semua tingkat laba yang mungkin diperoleh dari investasi. Usaha untuk mengurangi variabilitas laba tersebut dapat dilakukan dengan cara meningkatkan jumlah laba yang di laporkan, jika laba yang seharusnya dilaporkan lebih kecil dari Expected Profit, atau menurunkan jumlah laba yang dilaporkan jika laba yang seharusnya dilaporkan lebih besar dari Expected Profit .

\section{Bentuk- Bentuk Perataan Laba}

Menurut Scott (2003:405) bentuk-bentuk manajemen laba yang dilakukan oleh manajer antara lain: (a) Taking a bath, dilakukan ketika keadaan buruk yang tidak menguntungkan tidak bisa dihindari pada periode berjalan, dengan cara mengakui biaya-biaya pada periode-periode yang akan datang dan kerugian periode berjalan. (b) Income minimization, dilakukan saat perusahaan memperoleh profitabilitas yang tinggi dengan tujuan agar tidak mendapat perhatian secara politis. Kebijakan yang diambil bisa berupa pembebanan pengeluaran iklan, riset 
dan pengembangan yang cepat dan sebagainya. Cara ini mirip dengan taking a bath namun kurang ekstrim. (c) Income maximization, yaitu memaksimalkan laba agar memperoleh bonus yang lebih besar. Dimikian pula dengan perusahaan yang mendekati suatu pelanggaran kontrak hutang jangka panjang, manajer perusahaan tersebut akan cenderung untuk memaksimalkan laba. (d) Income smoothing, merupakan bentuk manajemen laba yang paling sering dilakukan dan paling populer. Lewat income smoothing,manajer menaikkan atau menurunkan laba untuk mengurangi fluktuasi laba yang dilaporkan sehingga perusahaan terlihat stabil dan tidak beresiko tinggi.

\section{Pemicu Perataan Laba}

Manajemen laba merupakan salah satu faktor yang dapat mengurangi kredibilitas laporan keuangan. Praktek manajemen laba akan menambah bias dalam laporan keuangan dan dapat mengganggu pemakai laporan keuangan yang mempercayai hasil rekayasa tersebut sebagai angka-angka atas laporan keuangan tanpa rekayasa.

Perilaku manajemen laba dapat dijelaskan melalui Positive Accounting Theory (PAT) dan Agency Theory. Tiga hipotesis PAT yang dijadikan dasar pemahaman tindakan manajemen laba yang dirumuskan oleh Watts dan Zimmerman (1986:201) adalah, Pertama; The Bonus Plan Hypothesis. Pada perusahaan yang memiliki rencana pemberian bonus, manajer perusahaan akan lebih memilih metode akuntansi yang dapat menggeser laba dari masa depan ke masa kini sehingga dapat menaikkan laba saat ini. Hal ini dikarenakan manajer lebih menyukai pemberian upah yang lebih tinggi untuk masa kini. Dalam kontrak 
bonus dikenal dua istilah yaitu bogey (tingkat laba terendah untuk mendapatkan bonus) dan cap (tingkat laba tertinggi). Jika laba berada di bawah bogey, tidak ada bonus yang diperoleh manajer sedangkan jika laba berada di atas cap, manajer tidak akan mendapat bonus tambahan. Jika laba bersih berada di bawah bogey, manajer cenderung memperkecil laba dengan harapan memperoleh bonus lebih besar pada periode berikutnya, demikian pula jika laba berada di atas cap. Jadi hanya jika laba bersih berada di antara bogey dan cap, manajer akan berusaha menaikkan laba bersih perusahaan.

Kedua: The Debt to Equity Hypothesis (Debt Covenant Hypothesis). Pada perusahaan yang mempunyai rasio debt to equity tinggi, manajer perusahaan cenderung menggunakan metode akuntansi yang dapat meningkatkan pendapatan atau laba. Perusahaan dengan rasio debt to equity yang tinggi akan mengalami kesulitan dalam memperoleh dana tambahan dari pihak kreditor bahkan perusahaan terancam melanggar perjanjian utang.

Ketiga, The Political Cost Hypothesis (Size Hypothesis). Pada perusahaan besar yang memiliki biaya politik tinggi, manajer akan lebih memilih metode akuntansi yang menangguhkan laba yang dilaporkan dari periode sekarang ke periode masa mendatang sehingga dapat memperkecil laba yang dilaporkan. Biaya politik muncul dikarenakan profitabilitas perusahaan yang tinggi dapat menarik perhatian media dan konsumen.

Agency theory memiliki asumsi bahwa masing-masing individu sematamata termotivasi oleh kepentingan diri sendiri sehingga menimbulkan konflik kepentingan antara principal dan agent. Pemegang saham sebagai pihak principal mengadakan kontrak untuk memaksimumkan kesejahteraan dirinya dengan 
profitabilitas yang selalu meningkat. Manajer sebagai agent termotivasi untuk memaksimalkan pemenuhan kebutuhan ekonomi dan psikologisnya antara lain dalam hal memperoleh investasi, pinjaman, maupun kontrak kompensasi. Masalah keagenan muncul karena adanya perilaku oportunistik dari agent, yaitu perilaku manajemen untuk memaksimumkan kesejahteraannya sendiri yang berlawanan dengan kepentingan principal. Manajer memiliki dorongan untuk memilih dan menerapkan metode akuntansi yang dapat memeperlihatkan kinerjanya yang baik untuk tujuan mendapatkan bonus dari principal.

Menurut Scott (2003:411) beberapa motivasi yang mendorong manajer perusahaan untuk melakukan manajemen laba, yaitu: Pertama, Bonus scheme; adanya asimetri informasi antara manajer dengan investor berkenaan dengan laba bersih yang akan dilaporkan dalam laporan keuangan, dimana pihak manajer mempunyai informasi lebih sebelum dilaporkan dalam laporan keuangan sedangkan pihak luar dan investor tidak bisa mengetahui sampai mereka membaca laporan keuangan tersebut. Oleh karena itu, manajer perusahaan akan berusaha untuk mengatur tingkat laba bersih berdasarkan kontrak perjanjian mereka dengan perusahaan sehingga dapat memaksimalkan tingkat bonus yang mereka terima.

Kedua, Debt covenant atau kontrak jangka panjang merupakan perjanjian yang dibuat antara kreditur dan debitur dengan tujuan untuk melindungi kepentingan kreditur atas tindakan-tindakan yang dilakukan manajer perusahaan. Tindakan-tindakan yang dapat menurunkan tingkat keamanan atau menaikkan resiko kreditur seperti pembagian deviden yang berlebihan, pemberian pinjaman yang berlebihan ataupun memberikan modal kerja kepada pemilik diatas perjanjian yang telah ditetapkan. Manajemen laba dalam konteks Debt Covenant 
sering dilakukan perusahaan yang berada dalam ancaman kebangkrutan agar tetap bertahan. Ketiga, Political Motivation. Adanya aspek politis tidak dapat dipisahkan dari operasional suatu perusahaan, khususnya perusahaan dalam skala besar dan industri strategis yang aktivitasnya melibatkan hajat hidup orang banyak. Perusahaan seperti ini cenderung untuk menurunkan labanya, misalnya dengan praktik dan prosedur akuntansi. Keempat, Taxation Motivation. Masalah perpajakan merupakan salah satu alasan mengapa pihak manajemen perusahaan berusaha mengurangi tingkat laba bersih yang dilaporkan agar nilai pajak yang harus ditanggung dapat diperkecil. Kelima, Pergantian CEO (Chief Executive Officer). Adanya pergantian CEO biasanya diikuti dengan fenomena manajemen laba dimana seorang CEO yang mendekati masa akhir jabatannya biasanya berusaha memaksimalkan laba yang dilaporkan agar tingkat bonus yang mereka terima bisa lebih tinggi. Demikian pula apabila CEO yang kurang berhasil dalam meningkatkan kinerja perusahaannya kadang berusaha melakukan manipulasi biaya yang akan datang dimana ia mengakui biaya yang akan datang dengan harapan mendapatkan tingkat laba yang lebih tinggi dimasa mendatang.

Keenam, Initial Public Offerings (IPO). Perusahaan yang melakukan penawaran saham untuk pertama kalinya biasanya dihadapkan pada masalah penentuan harga saham yang ditawarkan, karena perusahaan tersebut belum mempunyai harga pasar. Untuk itu perusahaan cenderung melakukan manajemen laba untuk memperoleh harga saham sesuai dengan keinginannya, dengan cara memanipulasi tingkat laba bersih. Laba bersih dalam laporan keuangan dalam prospektus merupakan sumber informasi yang dapat menarik investor, karena laba bersih sering dianggap investor sebagai suatu "sinyal" mengenai nilai perusahaan. 
Ketujuh, Mengkomunikasikan Informasi pada Investor. Efisiensi pasar relatif terhadap ketersediaan informasi secara publik. Jika manajemen laba dapat mengungkapkan inside information, maka hal tersebut dapat meningkatkan informasi pelaporan keuangan. Jika laporan laba diatur agar mewakili manajemen dalam mengestimasi kekuatan laba secara terus menerus, dan pasar mewujudkannya, harga saham secara cepat akan mencerminkan inside information tersebut.

\section{Strategi Dalam Manajemen Laba}

Teknik yang digunakan dalam merekayasa laba menurut Setiawati dan Naim (2000) dikelompokkan menjadi 3 kelompok, yaitu: (a) Memanfaatkan peluang untuk membuat estimasi akuntansi. Cara manajemen untuk mempengaruhi laba melalui judgement terhadap estimasi akuntansi antara lain, estimasi tingkat piutang tak tertagih, estimasi kurun waktu depresiasi aktiva tetap atau amortisasi aktiva tak berwujud, estimasi biaya garansi, dll. (b). Mengubah metode akuntansi. Perubahan metode akuntansi yang digunakan untuk mencatat suatu transaksi, contoh: merubah metode depresiasi aktiva tetap, dari metode depresiasi angka tahun ke metode depresiasi garis lurus. (c) Menggeser periode biaya atau pendapatan. Beberapa orang menyebut rekayasa jenis ini sebagai manipulasi keputusan operasional. Contoh, rekayasa periode biaya atau pendapatan antara lain: mempercepat/menunda pengeluaran untuk penelitian sampai periode akuntansi berikutnya, mempercepat/menunda pengeluaran promosi sampai periode akuntansi berikutnya, kerjasama dengan vendor untuk mempercepat/menunda pengiriman tagihan sampai periode akuntansi berikutnya, 
mempercepat/menunda pengiriman produk ke pelanggan, menjual investasi sekuritas untuk memanipulasi tingkat laba, mengatur saat penjualan aktiva tetap yang sudah dipakai, dan lain-lain. Perusahaan yang mencatat persediaan menggunakan asumsi LIFO, juga dapat merekayasa peningkatan laba melalui pengaturan saldo persediaan.

\section{Alasan dan Motivasi Manajer Melakukan Manajemen Laba}

Menurut Assih dan Gudono ( 2000 ), perataan laba merupakan perilaku yang rasional didasarkan pada asumsi dalam Positive Accounting Theory (PAT) dimana agent (manajemen) adalah individual yang rasional, yang memperhatikan kepentingan dirinya. Konsisten dengan asumsi tersebut, maka motivasi yang mempengaruhi pilihan manajer atas kebijakan tertentu adalah memaksimalkan kepentingannya. Motivasi dalam melakukan perataan laba ini biasanya adalah untuk kepuasan 2 kelompok, yaitu : pengguna eksternal (meliputi investor dan kreditur) dan pengguna internal informasi akuntansi (Brayshaw dan Eldin,1989). Selain itu, Brayshaw dan Eldin (1989) juga mengungkapkan bahwa adanya ancaman penggantian manajemen merupakan salah satu alasan manajemen perusahaan untuk melakukan income smoothing.

Hepworth dalam Salno dan Baridwan (2000), mengungkapkan bahwa manajer yang termotivasi untuk melakukan perataan laba pada dasarnya ingin memperoleh berbagai keuntungan ekonomi dan psikologis, yaitu: 1.) Mengurangi pajak terhutang; 2.) Meningkatkan kepercayaan diri manajer, karena penghasilan yang stabil mendukung kebijakan deviden yang stabil pula; 3.) Meningkatkan hubungan antara manajer dengan karyawan, karena pelaporan penghasilan yang 
meningkat tajam memberi kemungkinan munculnya tuntutan kenaikan gaji dan upah; serta 4.) Siklus peningkatan dan penurunan penghasilan dapat ditandingkan dan gelombang pesimisme dan optimisme dapat diperlunak.

Di lain pihak, Brayshaw dan Eldin (1989) mengungkapkan 2 alasan mengapa manajemen diuntungkan dengan adanya praktik perataan laba,yaitu : (a) Skema kompensasi manajemen dihubungkan dengan kinerja perusahaan yang disajikan dalam laba akuntansi yang dilaporkan. Oleh karena itu, setiap fluktuasi dalam laba akan berpengaruh langsung terhadap kompensasinya. (b) Fluktuasi dalam kinerja manajemen dapat mengakibatkan intervensi pemilik untuk mengganti manajemen dengan cara pengambilalihan atau penggantian manajemen secara langsung. Ancaman penggantian ini mendorong manajemen untuk membuat kinerja yang sesuai dengan keinginan pemilik.

Menurut Brochet dan Gildao dalam Suranta dan Merdistusi (2004), motivasi yang mendasari para manajer melakukan perataan laba antara lain, (1) Kompensasi yang diterima manajer tidak sesuai dengan kinerja yang mereka hasilkan ( job security hypothesis). (2) Jumlah saham yang dimiliki para manajer, besar kecilnya jumlah saham yang dimiliki manajer mempengaruhi teradinya praktik income smoothing, karena manajer berusaha melakukan pensejajaran (alignment) dengan para share holders. (3) Tidak adanya mekanisme mentoring yang efektif. (4) Pasar modal yang sangat kompetitif dapat mendorong manajer untuk melakukan praktik income smoothing dengan cara meningkatkan kinerja yang buruk (poor performance) dan melakukan safety performance pada saat perusahaan mengalami kinerja yang sangat baik. (5) Masa jabatan CEO (Chief Exceutive Officers), semakin lama masa jabatan CEO dapat mempengaruhi 
keputusan yang diambil oleh para dewan direksi dan mempengaruhi mekanisme corporate governance. (6) $C E O$ berperan dalam pengungkapan dan penyajian laporan keuangan, sehingga mereka dapat lebih berpengaruh daripada dewan direksi.

Menurut Belkaoui (2000:58), terdapat tiga kendala yang dapat menggiring manajer untuk melakukan perataan laba, yaitu; (1) mekanisme pasar kompetitif, yang mengurangi pilihan bagi manajemen, (2) skema kompensasi manajemen, yang secara langsung terkait dengan kinerja perusahaan; dan (3) ancaman penggantian manajemen.

\section{Berbagai Pendapat Tentang Earning Management}

Tindakan perataan penghasilan bersih atau laba merupakan tindakan yang umum atau rasional (Jatiningrum, 2000). Praktik perataan laba merupakan fenomena yang umum terjadi sebagai usaha manajemen untuk mengurangi fluktuasi laba yang dilaporkan (Narsa, et al, 2003). Tindakan perataan laba adalah suatu sarana yang dapat digunakan manajemen untuk mengurangi fluktuasi pelaporan penghasilan dan memanipulasi variabel-variabel (akuntansi) semu atau dengan melakukan transaksi-transaksi riil (Brayshaw dan Eldin, 1989). Bagi manajemen, seringkali tidak penting untuk melaporkan laba maksimal, bahkan manajemen lebih cenderung melaporkan laba yang dianggap normal bagi perusahaan untuk beberapa periode (Samlawi dan Sudibyo, 2000).

Tindakan perataan laba ini menyebabkan pengungkapan informasi mengenai penghasilan bersih/laba menjadi menyesatkan, sehingga akan mengakibatkan terjadinya kesalahan dalam pengambilan keputusan oleh pihak- 
pihak yang berkepentingan dengan perusahaan, khususnya pihak eksternal (Jatiningrum, 2000). Perataan laba menjadi suatu hal yang merugikan investor, karena investor tidak akan memperoleh informasi yang akurat mengenai laba untuk mengevaluasi tingkat pengembalian dari portofolionya. Tindakan perataan laba mengakibatkan pengungkapan dalam laporan keuangan menjadi tidak memadai (Dwiatmini dan Nurkholis, 2001). Fenomena ini merupakan dampak negatif asimetri informasi dalam konsep teori keagenan.

Perataan laba dalam laporan keuangan merupakan hal yang biasa dan dianggap masuk akal (Bartov, 1993). Hal ini memang cukup banyak mengundang kontroversi, di satu sisi earnings management merupakan tindakan yang tidak menyalahi peraturan yang ada dan berlaku umum.

\section{Etika}

Apakah etika itu ? Etika merupakan ilmu yang mendalami standar moral perorangan dari standar moral masyarakat. Ia mempertanyakan bagaimana standar-standar diaplikasikan dalam kehidupan kita dan apakah standar ini masuk akal atau tidak masuk akal (Velasquez, 2002:15). Seseorang mulai memperdulikan etika ketika dia menggunakan standar moral yang diserap dari keluarga, teman dan bertanya: apakah standar-standar tersebut mengacu pada situasi yang saya hadapi ? Apakah standar tersebut masuk akal? Apakah alasan untuk mendudung atau menentang standar tersebut. Apakah yang dapat dikatakan untuk mendukungnya dan untuk melawannya? Apakah cukup masuk akal untuk saya anut? 
Etika yang berasal dari sebuah kata Yunani "ethos" (Rahardjo, 1990:3) pada hakekatnya memiliki arti "filsafat mengenai bidang moral" (Suseno, 1997: 6). Bidang moral mengarah pada perilaku manusia, dengan demikian etika dapat dikatakan sebagai suatu penyelidikan atau pengkajian secara sistematis mengenai perilaku (Rahardjo, 1990: 4).

Dewasa ini diskusi etika dalam tataran teoritis kebanyakan lebih merujuk pada dua pengelompokan pemikiran besar, yaitu etika teleologi dan etika deontologi (Ludigdo, 2007:31) dua pemikiran ini telah menjadi mainstream dalam mencari pedoman untuk pengembangan praktik etika. Etika teleologi dikembangkan terutama oleh tokoh-tokoh besar pemikir etika dari eropa seperti Jeremy Bentham dan John Stuart Mill (Cryssides dan Kaler, 1993:91 dan Suseno, 1997:179). Etika teleologi ini juga dikenal sebagai etika konsekuensialisme (Cryssides dan Kaler, 1993:91), mempunyai pandangan mendasar bahwa suatu tindakan dinilai baikatau buruk berdasarkan tujuan atau akibat dilakukannya tindakan tersebut. Oleh karena tidak mudah menilai baik buruknya tujuan atau akibat suatu tindakan dalam kerangka teleologi, maka muncullah varian darinya yaitu egoisme dan utilitarianisme (Keraf dan Imam, 1991:31). Etika egoisme menilai baik buruknya tindakan dari tujuan dan manfaat tindakan tersebut bagi pribadi-pribadi. Landasan pemikiran ini adalah satu-satunya tujuan moral setip pribadi adalah untuk mengejar kepentingannya dan memajukan dirinya sendiri. Pada akhirnya egoisme cenderung menjadi hedonisme, dimana tindakan baik dan buruk dinilai berdasarkan kebahagian atau kesenangan yang diakibatkannya. Kebahagian dan kesenangan tersebut biasanya bersifat lahiriah dan diukur 
berdasarkan kebahagian dan kesenangan yang berupa materi. Di sinilah kemudian pemikiran materialisme menjadi berkembang.

Kant menyatakan etika bahwa suatu etika yang sangat keras: dusta itu dusta, biarpun menyelamatkan manusia (Peursen, 1991:228). Selain mengendalikan kehedonismean, etika mutlak diperlukan karena (Suseno, 1991:15): (1) etika dapat memberikan capaian suatu pendirian dalam pergolakan pandangan-pandangan moral, (2) etika membantu manusia agar jangan kehilangan orientasi dan membedakan antara apa yang hakiki serta apa yang boleh berubah, (3) etika membuat manusia sanggup untuk menghadapi ideologi-ideologi dengan kritis dan objektif serta membentuk penilaian sendiri, dan (4) di etika dapat ditemukan dasar kemantapan tanpa menutup diri dalam semua dimensi kehidupan masyarakat yang terus berubah. Etika bisnis diperlukan sebagai pengendali "bermain" di bisnis dimana dalam memberlakukannya tidak dapat dilakukan penyeragaman. Etika bisnis harus selaras dengan kultur dimana pemain berlaga. Oleh Triyuwono (1997) hal yang demikian dikatakan sebagai culture bond, artinya etika tersebut merupakan kristalisasi dari nilai-nilai (luhur) yang dimiliki masyarakat. Perkembangan bisnis yang demikian cepat kerapkali memaksa pelaku bisnis memeras otak untuk memenangkan persaingan. Terkadang penggunaan prinsip ekonomi "mendapatkan keuntungan semaksimal mungkin dengan biaya terkecil" memicu munculnya ketidaketisan dalam praktek bisnis (unfair businessnpractice). Penelitian yang dilakukan Lee dan Yoshihara dalam Nggao (1998) menyimpulkan bahwa responden Korea dan Jepang masing-masing sebesar $57,6 \%$ dan $60,8 \%$ melakukan tindak etis yang disebabkan oleh nilai pribadi. 
Hedonisme yang berasal dari bahasa Yunani "hedone" sangat erat berhubungan dengan nilai pribadi yang dimiliki manusia. Hedonisme bertolak ada pendirian bahwa menurut kodratnya manusia mengusahakan kenikmatan (Devos, 1987:161) dan menjauhi rasa sakit (Rahardjo, 1990: 23). Singkatnya manusia selalu menolak sesuatu yang tidak mengenakkan individunya. Tesis yang di bangun tersebut sudah lama ada dalam Al-Quran (Mahmud, 1973:27): .....Ya. Tuhan kami, janganlah engkau pikulkan pekerjaan yang berat diatas pundak kami......(QS.2:286) dan ....apabila manusia ditimpa kesusahan maka ia (berdo’a) dengan do'a yang lebar panjang (Qs. 41:51).

Pertumbuhan dan perkembangan ekonomi memicu materialisme, konsumerisme dan hedonisme (Amin, 2005:74). Artinya tumbuh kembangnya hedonisme tidak bisa lepas dari pertumbuhan dan perkembangan ekonomi. Semakin pesat tumbuh dan kembangnya perekonomian akan diikuti dengan besarnya hedonisme. Hedonisme mengajarkan bahwa apa yang dinikmati tidak dipermasalahkan yang penting kenikmatan tersebut berharga (Devos, 1987:162). Dari sisi psikologis, hedonisme memainkan peran yang cukup penting terjadinya earning management. Karena hedonisme bertolak dari anggapan bahwa manusia hendaknya hidup sedemikian rupa sehingga dapat semakin bahagia (Suseno, 1991:113). Lebih lanjut Suseno (1991:114) menambahkan, hedonisme seringkali mendasarkan pada teori hedonisme psikologis dimana teori tersebut menyatakan bahwa manusia, bagaimanapun hanya mencari nikmat dan mau menghindari perasaan-perasaan yang tidak enak. Bahkan dalam hedonisme materialitas kuantitatif, dinyatakan bahwa manusia hendaknya hidup sesuai dengan kodratnya. Kodrat manusia yang paling hakiki adalah, menjauhi rasa sakit dan mengejar rasa 
nikmat (Rahardjo, 1990:23). Dan hedonisme menganggap tujuan tindakan manusia berkecenderungan dasar untuk mencari manfaat dalam segala tindakan untuk mendapatkan kebahagiaan dalam jumlah besar. Namun masih ada aliran hedonisme lain yang mengakui dan mengunggulkan kenikmatan rohani.

Income smoothing salah satu teknis earning management oleh manajemen untuk mengurangi variabilitas pendapatan/laba yang dilaporkan untuk tujuan tertentu (Mahmudi, 2001), seperti: untuk mengurangi pajak entitas, memperbaiki hubungan dengan rekanan bisnis dengan menunjukkan bahwa entitas beresiko rendah. Income smoothing bisa dilakukan dengan beberapa cara, menurut Ayres dalam Gumanti (2003) yakni: (1) manajemen akrual, (2) peneapan suatu kebijakan akuntansi yang wajib, dan (3) perubahan akuntansi secara sukarela (voluntary accounting changes).

Manajemen akrual dilakukan dengan cara mempercepat atau menunda pengakuan untuk pendapatan, mengakui biaya sebagai tambahan investasi. Aktivitas mempercepat atau menunda pendapatan akan terlihat capaian besarnya income (laba) oleh entitas. Penundaan pengakuan pendapatan kedalam laporan laba rugi dilakukan manajemen pada saat penjualan melebihi target. Dan kelebihan tersebut akan dipergunakan pada periode berikutnya bila penjualan di bawah target atau dengan kata lain mempercepat pengakuan pendapatan tersebut (seharusnya pada periode sebelumnya pendapatan harus sudah dilaporkan). Pada akhirnya aktivitas ini mengatur tampilan pendapatan agar terlihat stabil. Selain mempercepat atau menunda pengakuan pendapatan, manajemen bisa bermainmain dengan biaya piutang ragu-ragu. Dan tentunya permainan ini akan berdampak pada cadangan kerugian piutang tak tertagih. Penentuan pengakuan 
biaya piutang ragu-ragu yang lebih kecil dari seharusnya aka memicu besarnya income (laba). Dan ini akan memperbesar assets entitas. Dengan demikian user laporan keuangan tidak mendapatkan gambaran yang sesungguhnya atas sesuatu yang terjadi pada suatu entitas. Meskipun dalam laporan keuangan memiliki konsep dasar konsistensi atas penggunaan metode akuntansi bukan berarti perubahan metode akuntansi dilarang. Dan manajemen bisa melakukan income smoothing dengan mengubah metode akuntansi. Mungkin perubahan metode akuntansi cukup sekali saja. Semakin sering mengubah metode akuntansi menunjukkan bahwa laporan keuangan yang dimiliki entitas tidak berkualitas.

Masih banyak upaya income smoothing, diantaranya mempercepat atau memperlambat menerapkan kebijakan akuntansi baru oleh standar profesi yang tertuang dalam standar akuntansi keuangan. Biasanya organisasi profesi akan memberikan tenggang waktu batas kapan harus dilaksanakan kebijakan tersebut. Tawaran kebijakan akan disegera dilaksanakan bila manajemen melihat keuntungan yang diraihnya bila diterapkan kebijakan baru. Penggunaan kebijakan baru tersebut diteliti oleh Ayres, Trombley, dan Gujarati dan Hoskin dalam Gumanti (2003). Mereka memberikan simpulan: penggunaan kebijakan baru lebih awal akan menaikkan keuntungan entitas. Penerapan kebijakan baru lebih akan mempengaruhi prestasi manajemen.

Hasil penelitian menunjukkan bahwa earning management yang merupakan wewenang manajemen ini bersifat legal dan tidak melanggar standar akuntansi yang ditetapkan. Namun demikian masih terjadi kontroversial sekitar earning management kelegalan. Pengungkapan atas laporan keuangan bagi user yang disajikan oleh suatu entitas bisa menyesatkan bahkan tidak menutup 
kemungkinan user mengambil keputusan yang tidak terarah. Artinya pembohongan terhadap publik melalui laporan keuangan untuk kepentingan pribadi terjadi dalam earning management. Bagi pemilik (owner) pun awalnya merasa bangga dengan capaian organisasi yang dimilikinya namun dalam meramal (forecasting) ke depannya perlu dipertanyakan kevalidannya. Data-data times series yang akan memproyeksikan ramalan ke depan banyak salah karena banyak manipulasi data dilakukan oleh manajemen. Ujung-ujungnya keetisan earning management mulai dipertanyakan dalam dunia bisnis. Jawaban keetisan tersebut amat terkait dengan empat masalah yang ada dalam etika bisnis (Mahmudi, 2001), yaitu: (1) benturan kepentingan pribadi dengan pihak lain, (2) tekanan untuk menghasilkan laba, (3) ketidaksesuaian nilai pribadi dengan tujuan bisnsi dan (4). kontrakdiksi lintas kultural. Melihat empat masalah dalam etika bisnis tersebut memposisikan motivasi mengapa manajemen melakukan earning management.

Motivasi mengapa manajemen perusahaan melakukan earning management tidak dapat lepas dari individu sebagai pelakunya.. Dengan mengabaikan kepentingan user eksternal atas laporan keuangan bahkan pengabaian kepentingan pemilik (owner) menunjukkan indikasi kepentingan individu menjadi prioritas. Prioritas kepentingan individu ini suatu peristiwa perilaku manusia yang berupaya mewujudkan kenikmatan. Dengan earning manajemen yang di manage sedemikian rupa oleh manajemen sehingga tampak kinerjanya bagus. Sebagai kompensasi atas kinerja yang telah dihasilkan tersebut owner memberikan suatu reward (materiil/ non materiil). Pemberian reward ini juga perlu dipertanyakan bila reward dalam bentuk uang kontan. Reward akan 
memberatkan entitas karena laporan keuangan khususnya laporan laba rugi menggunakan konsep accrual basic. Artinya entitas akan terberati karena capaian manajemen hasil dari earning management belum terwujud uang tunai.

Kondisi upaya mencari kenikmatan melalui earning management tanpa menghiraukan kepentingan pihak lain ini merefleksikan dari eksistensi sifat egoistik manusia (Triyuwono, 1997). Menurut Giddens (1986:143) sifat egoistik tersebut dimiliki oleh setiap pribadi yang sekaligus pribadi-pribadi tersebut sebagai makhluk sosial. Manusia sebagai sosok makhluk sosial memiliki kepentingan bersama dan berkelompok (social survival) yang harus rela menjalin kerjasama dengan sesamanya (Amin, 2005:142) ini memiliki kesadaran manusia. Kesadaran tersebut oleh Freud unsur-unsur di identifikasi sebagai Id, Ego dan superego (Suseno, 1991:87). Lebih lanjut dapat dijelaskan mengenai unsur-unsur kesadaran manusia sebagai berikut: Id merupakan kesadaran manusia yang irrasional yang muncul dari kedalam diri dan menghadapkan manusia akan tuntutan kebutuhannya. Sedangkan ego dapat diartikan kita sendiri (Suseno, 1991: 88) yang dihadapkan pada tiga realitas: (1) alam, (2) manusia-manusia lain dan (3) Id. Dan unsur kesadaran manusia yang terakhir, superego yang merupakan alat evaluasi atas tindakan manusia karena di unsur kesadaran manusia ini terdapat perasaan bersalah bila perbuatan untuk memenuhi id adalah terlarang.

Hedonisme yang merupakan bagian dari tiga teori etika normatif selain teori pengembangan diri dan utilisarisme ini berpandangan bahwa manusia mencapai kebahagiaan dengan mencari nikmat. Dengan hedonisme maka id manusia akan terpenuhi. Earning management dalam prakteknya bersifat legal tidak melanggar prinsip-prinsip akuntansi yang berterima umum (Mahmudi, 
2001). Namun bila ditinjau lebih jauh untuk aktivitas tersebut (earning management) cenderung berlawanan dengan kepentingan owner karena disana terdapat upaya memaksimumkan kesejahteraan individu (manajemen). Capaian tujuan melalui manage atas laba akan memperlihatkan pada publik bahwa suatu entitas dalam kondisi aktivitas yang sehat. Namun bila ditelusuri lebih lanjut akan berdampak untuk pengambilan keputusan (decison making) yang keliru karena adanya earning management. Dengan earning management yang dilakukan manajemen akan memberikan suatu barometer kinerja yang diharapkan oleh owner yaitu entitas yang mampu menciptakan laba (income). Pencapaian target laba yang dipatok oleh prinsipal (owner) akan memberikan kenikmatan pada manajemen baik materiil / non materiil.

\section{KESIMPULAN}

Earning management merupakan masalah yang kontroversial. Pada satu sisi, praktik earning management bersifat legal tanpa melanggar prinsip akuntansi berterima umum. Namun disisi lain earning management oleh Poedjawiyatna dalam Mahmudi (2001) ini dapat dikatakan perbuatan yang tidak etis dan tidak bermoral. Kebutuhan hedonisme dalam dunia bisnis bisa dipenuhi dengan earning management.

Sebelum disimpulkan earning management yang terjadi karena horizon problem antara manajemen dengan owner dari pandangan hedonisme terlebih dahulu perlu sedikit diulas apakah hedonisme itu benar?. Untuk itu perlu diperiksa dua hal (Suseno, 1991:115): (1) apakah benar manusia dalam segala usahannya hanya mencari nikmat saja dan mau menghindari dari yang tidak enak (hedonisme 
psikologis) dan (2) apakah benar manusia akan menjadi bahagia asal saja dan menghidari perasaan yang menyakitkan (hedonisme etis).

Hedonisme psikologis mengutarakan bahwa manusia selalu tertarik oleh perasaan nikmat dan cenderung menolak atau menghindari perasaan yang tak nikmat. Earning management bila dilihat dari kacamata hedonisme psikologis, manajemen yang melakukannya ada dua kemungkinan: (1) dorongan spontan dan (2) tidak dengan dorongan yang spontan. Manajemen dalam melakukan earning management, ia bertindak dengan suatu pertimbangan. Pemilihan cara dalam earning management seperti penggunaan metode akuntansi atau kapan ia harus menahan atau mempercepat record laba (income) dalam suatu laporan laba rugi.

Argumen pokok dalam hedonisme etis: manusia akan bahagia bila ia mencapai perasaan nikmat sebanyak mungkin dan menghindari perasaan tak enak (Suseno, 1991:117). Harus diakui manajemen sebagai pemegang amanah dari owner berusaha sekeras mungkin untuk meminimalisasi punishment yang diberikan owner karena tidak dapat mencapai target. Dan upaya mendapatkan reward menjadi prioritas manajemen, reward diperoleh dengan menunjukkan prestasi kerja yang stabil dari beberapa periode. Earning management salah satu jalan menunjukkan prestasi tersebut. Dengan melihat dua sudut pandang hedonisme psikologis dan hedonisme etis maka dapat ditarik suatu simpulan bahwa earning management adalah tindakan yang wajar untuk memenuhi hedonisme manusia itu sendiri. 


\section{DAFTAR PUSTAKA}

Almilia, L.S. \& Kristijadi .(2003). Analisis Rasio Keuangan Untuk Memprediksi Kondisi Financial Distress Perusahaan Manufaktur Yang Terdaftar di Bursa Efek Jakarta. Jurnal Akuntansi dan Auditing Indonesia,Vol.7, No.2 : 183208.

Amin, M Abdullah. (2005). Pendidikan Agama: Era Multikultural-Multireligius. Jakarta : PSAP Muhammadiyah.

Assih, Prihat \& Gudono, M. (2000). Hubungan Tindakan Perataan Laba dengan Reaksi Pasar atas Pengumuman Informasi Laba Perusahaan yang Terdaftar di Bursa aEfek Jakarta. Jurnal Riset Akuntansi Indonesia, Vol 3, No 1 : 3553.

Bartov, Eli.(1993). The Timing of Assets Sales and Earning Manipulation. The Accounting Review. Vol. 68, No. 4, p. 840-855.

Beekun, R.I. (1997). Islamic Business Etchics. International Institute of Islamic Thought, Herdon, Virginia, USA.

Belkaoui, A. R.. (1999). Teori Akuntansi. Buku Satu. Terjemahan Marwanta, Hanjanti Widyastuti, Heni Kurniawan dan Alia Ariesanti. 2000. Jakarta: Salemba Empat.

Bertens, K. (2000). Etika. Jakarta : PT. Gramedia Pustaka Utama.

Brayshaw, R.E \& Eldin, Ahmed E. K. (1989). The Smoothing Hypothesis and The Role of Exchange Differences. Journal of Business, Finance and Accounting, Vol. 16. No. 5, p. 621-633.

Chryssides, G.D. \& J.H. Kaler. (1993). An Introduction to Business Ethics. Chapman \& Hall, London.

Devos. (1987). Pengantar Etika. Yogjakarta: Tiara Wacana Jogja.

Dwiatmini, Sesilia \& Nurkholis. (2001). Analisis Reaksi Pasar Terhadap Informasi Laba : Kasus Paraktik Perataan Laba Pada Perusahaan yang Terdaftar di BEJ. TEMA. Vol. II : No. 1, p. 35-48.

Giddens, Anthony. (1986). Kapitalisme dan Teori Sosial Modern, Cetakan Pertama. Jakarta : UI - Press.

Gumanti, T. A. (2003). Motivasi di Balik Earning Management. Usahawan No. 12 TH XXXII Desember. Hal. 21-26. 
Harahap, Khairunnisa. (2004). Asosiasi antara Praktik Perataan Laba dengan Koefisien respon Laba. Proceedings Simposium Nasional Akuntansi VII. Denpasar : 1164-1176.

Jatiningrum. (2000). Analisis Faktor-faktor yang Berpengaruh Terhadap Perataan Penghasilan Bersih/Laba pada Perusahaan yang Terdaftar di BEJ. Jurnal Bisnis dan Akuntansi, Vol. 2, No. 2 : 145-155.

Keraf, S. \& R.H. Imam. (1991). Etika Bisnis. Yogyakarta : Kanisius.

Kompas. (2002). Tumbangnya Raksasa Ekonomi. Kompas, 15 Juli 2002. Hal. 4.

Ludigdo, Unti. (2007). Paradoks Etika Akuntan. Yogyakarta. Pustaka Pelajar.

Mahmud, Yunus.(1973). Tafsir Qur'an Karim. Jakarta : PT. Hidakarya Agung.

Mahmudi. (2001). Manajemen Laba (Earnings Management): Sebuah Tinjauan Etika Akuntansi, Jurnal Bisnis dan Akuntansi, Vol.3, No.2, Agustus, p. 395402.

Narsa, I Made; Nugraheni, Bernadetta Diana; Maritza, \& Benedikta. (2003). Faktor-faktor yang Mempengaruhi Praktik Perataan Laba Selama Krisis Moneter pada Perusahaan yang Terdaftar di Bursa Efek Suraaya. Majalah Ekonomi, Vol. XIII, No. 2, p.128-145.

Peursen, CA. Van. (1991). Orientasi Di alam Filasafat, PT. Gramedia, Jakarta.

Prasetio,J. Eko; Astuti, Sri; Wiryawan, \& Agung. (2002). Praktik Perataan Laba dan Kinerja Saham Perusahaan Publik di Indonesaia. Jurnal Akuntansi dan Auditing indonesia, Vol. 6, No. 2 : 45-63.

Rahardjo, M.Dawam. (1990). Etika Ekonomi dan Manajemen. Yogjakarta : PT. Tiara Wacana Jogja.

Salno., Meilani, Hana \& Baridwan, Zaki. (1998). Analisis Perataan Penghasilan (Income Smoothing) : Faktor-faktor yang mempengaruhi dan Kaitannya dengan Kinerja Saham Perusahaan Publik di indonesaia. Jurnal Riset Akuntasi Indonesia, Vol. 3, No. 1, p.17-34.

Samlawi, Ahmad \& Sudibyo, Bambang. (2000). Analisis Perataan Laba yang Didasarkan pada Kinerja Perusahaan di Pasar. Proceedings Simposium Nasional Akuntansi III , Jakarta : 150-169.

Scott, William R.(2003). Financial Accounting Theory. New Jersey : Prentice Hall.

Setiawati, Lilis \& Na'im, Ainun. (2000). Manajemen Laba. Jurnal Ekonomi dan Bisnis Indonesia, Vol. 15, No. 4 : 424-441. 
Sugiarto, Sopa. (2003). Perataan Laba dalam Mengantisipasi Laba Masa Depan Perusahaan Manufaktur yang Terdaftar di Bursa Efek Jakarta. Proceedings Simposium Nasional Akuntansi VII. Denpasar: 340-358.

Suranta, Eddy \& Merdistusi, Pratana Puspita. (2004). Income Smoothing, Tobin's Q, Agency Problems dan kinerja Perusahaan, Proceedings Simposium Nasional Akuntansi VII. Denpasar : 340-358.

Suseno, Franz Magniz. (1991). Etika Dasar: Masalah-Masalah Pokok Filsafat Moral. Yogjakarta : Kanisius.

Suseno, Franz Magniz. (1997). Etika Jawa. Jakarta : PT. Gramedia.

Triyuwono, Iwan. (1997). Pencerahan Diri, Media Akuntansi No.21/TH.IV/1997.

Watts, Ross L. \& Zimmerman, Jerold L. (1986). Positive Accounting Theory. Prentice Hall : International Edition.

Velasquez, Manuel G. (2002). Business Ethics, concepts and cases. New Jersey: Pearson Education. 